\title{
Effects of El Niño in Mexico during rainy and dry seasons: an extended treatment
}

\author{
José Luis BRAVO-CABRERA,* Enrique AZPRA-ROMERO, Víctor ZARRALUQUI-SUCH and \\ Carlos GAY-GARCÍA
}

Centro de Ciencias de la Atmósfera, Universidad Nacional Autónoma de México, Circuito de la Investigación Científica s/n, Ciudad Universitaria, 04510 Ciudad de México

*Corresponding author; email: jlbravo@atmosfera.unam.mx

Received: August 26, 2016; accepted: May 22, 2017

\section{RESUMEN}

Se analiza el efecto de El Niño-Oscilación del Sur (ENSO, por sus siglas en inglés) sobre la precipitación en México. A diferencia de estudios anteriores, en éste se maneja una mayor cantidad de datos y se cubre más extensamente el territorio mexicano. En este trabajo se emplearon los datos de precipitación diaria de la base de datos CLICOM a partir de 1961, actualizada hasta 2015. El periodo de estudio se dividió en dos fases: 1961 a 1990 y 1991 a 2013, y se consideraron también separadamente las épocas fría y seca del año (noviembre-abril), y la cálida y húmeda (mayo-octubre). De esta manera, la cantidad de estaciones que superan los criterios de cantidad de información continua para un periodo determinado, aumenta considerablemente. Se utiliza el coeficiente de correlación de Pearson con una significancia de 5\% para encontrar la relación entre la precipitación y el índice multivariado de ENSO (MEI, por sus siglas en inglés). Los resultados se presentan en mapas donde se observan regiones con precipitación por arriba o debajo del promedio. Claramente se identifica la región noroeste de México con una relación directa entre MEI y precipitación; mientras que se observa una relación inversa en la parte que se encuentra al sur del paralelo $22^{\circ} \mathrm{N}$, durante los meses de verano. En el periodo invernal existe un aumento generalizado de la precipitación conforme aumenta el MEI. Se muestra la distribución de la lluvia para periodos normales tanto de invierno como de verano.

\begin{abstract}
The effect of El Niño-Southern Oscillation (ENSO) on precipitation in Mexico is analyzed. Unlike previous studies, the amount of data used is larger and the Mexican territory is more widely covered. In this paper, daily precipitation from the CLICOM database updated to 2015 was used. The studied period spans from 1961 to 2013 and was divided into two periods: 1961-1990 and 1991-2013. For the same periods two separated seasons were considered: the cold and dry (November-April), and the warm and wet (May-October). Thus, the number of stations that exceed the amount of continuous information criteria for a certain period increases considerably. The Pearson correlation coefficient with a significance of $5 \%$ was used in order to test for the existence of a relationship between precipitation and the Multivariate ENSO Index (MEI). The results are presented in maps where regions of precipitation above or below average are observed. During the summer/ warm months, the northwestern region of Mexico is clearly identified with a direct relationship between MEI and precipitation, whereas an inverse relationship in the part that lies south of latitude $22^{\circ} \mathrm{N}$ is seen. In the winter/cold months, there is a general increase in precipitation with increasing MEI. Distributions of normal rainfall for both winter and summer are also shown.
\end{abstract}

Keywords: El Niño, precipitation, Pearson correlation, cold season, warm season. 


\section{Introduction}

Climate variations may be the cause of the apogee or decline of civilizations. For example, the fall of the Mayan civilization is thought to have been caused by a change in the position of the Intertropical Convergence Zone (ITCZ), which affected the thermal and humidity conditions needed to maintain the ecological balance in the region (Haug et al., 2003). The Pacific Decadal Oscillation (PDO), the Atlantic Multidecadal Oscillation (AMO) and El Niño-Southern Oscillation (ENSO) are some of the global climatic phenomena which may affect local conditions of temperature and humidity (Mantua et al., 1997; Méndez et al., 2010; Stahle et al., 2016). The oscillation of sea surface temperature above (positive phase) or below (negative phase) around its "normal values" is called PDO when present in the North Pacific (Bond and Harrison, 2000), and $\mathrm{AMO}$ when occurring in the Atlantic; the period of the former ranges from 10 to 40 years, while the latter by a few decades (Schlesinger and Ramankutty, 1994). El Niño-Southern Oscillation is an equatorial Pacific high-frequency anomaly compared to PDO or $\mathrm{AMO}$, its period ranging from three to seven years. To assess the effects of these global climate episodes on the local environment, it is necessary to consider local phenomena such as precipitation.

ENSO consists of three phases (Glantz, 2000):

a. El Niño, or warm phase, occurs when the anomaly of the SST is above average in the Eastern and Central Pacific; simultaneously in Indonesia, the amount of precipitation is reduced as opposed to Peru, Ecuador and contiguous regions of South America where it increases. This event is accompanied by changes in the intensity of trade winds, which even blow in the opposite direction.

b. La Niña, or cold phase, happens when the temperature anomaly is below normal, and trade winds strengthen causing rainfall higher than normal in the Indonesian region.

c. Neutral conditions occur when both SST and wind over the equatorial Pacific are close to normal.

The impact of El Niño has been studied in Mexico, mainly regarding precipitation. Salas-Flores et al. (2014) found that rain in the Yucatán Peninsula (Fig. 1) is modulated by the intensity of El Niño. Bravo et al.
(2010) found the relationship between El Niño and precipitation during the dry and wet seasons, and Magaña et al. (2003) discussed the frequency and intensity of cold fronts and their effect on the country during El Niño occurrence or absence. However, in those studies, a small number of stations that do not intensively cover the extension of the Mexican territory are used; in the later case the authors use information from reanalysis, which does not contain new information. El Niño effect on tropical cyclone activity has also been studied suggesting that during El Niño, the Atlantic tropical cyclones have a tendency to decrease, while during La Niña they tend to increase (Jáuregui, 1967; Gray, 1984). Also, when the number of tropical cyclones occurring in the Atlantic increases, it decreases in the Northeast Pacific and vice versa (Elsner and Kocher, 2000; Wang and Lee, 2009). Similarly, there are studies on the modulation exerted by the PDO on Mexico climate; Pavía et al. (2006) examined the PDO and ENSO combined effects on warm and cold seasons in temperature and precipitation; and Méndez et al. (2010) investigated it in regard to PDO only.

\section{Materials and methods}

A) Orography of the region

\subsection{Orography of the region}

Mexico is one of the few countries in the world that has coasts in two oceans: the Gulf of Mexico and the Caribbean Sea to the east in the Atlantic Ocean, and the Pacific Ocean to the west. Along the Pacific coast, its varied orography includes the Sierra Madre Occidental, the Sierra Madre del Sur and the Sierra de Chiapas; the first extends from the northern state of Sonora to the center in Colima, while the latest, as its name implies, lies on the southern state of Chiapas. Toward the Gulf of Mexico, the Sierra Madre Oriental runs from the state of Nuevo León at the north to the southern part of Veracruz. The territory narrows where the southern tip of Sierra Madre del Sur and Sierra Madre Oriental ends; in this place the Isthmus of Tehuantepec is located. The Isthmus of Tehuantepec is a plain that separates the Sierra de Chiapas from the above-mentioned ranges and represents the narrowest part of the Republic. The Yucatán Peninsula is a flat region that begins from the Isthmus of Tehuantepec and extends to northeast (Salgado et al., 2014). The Baja California Peninsula 


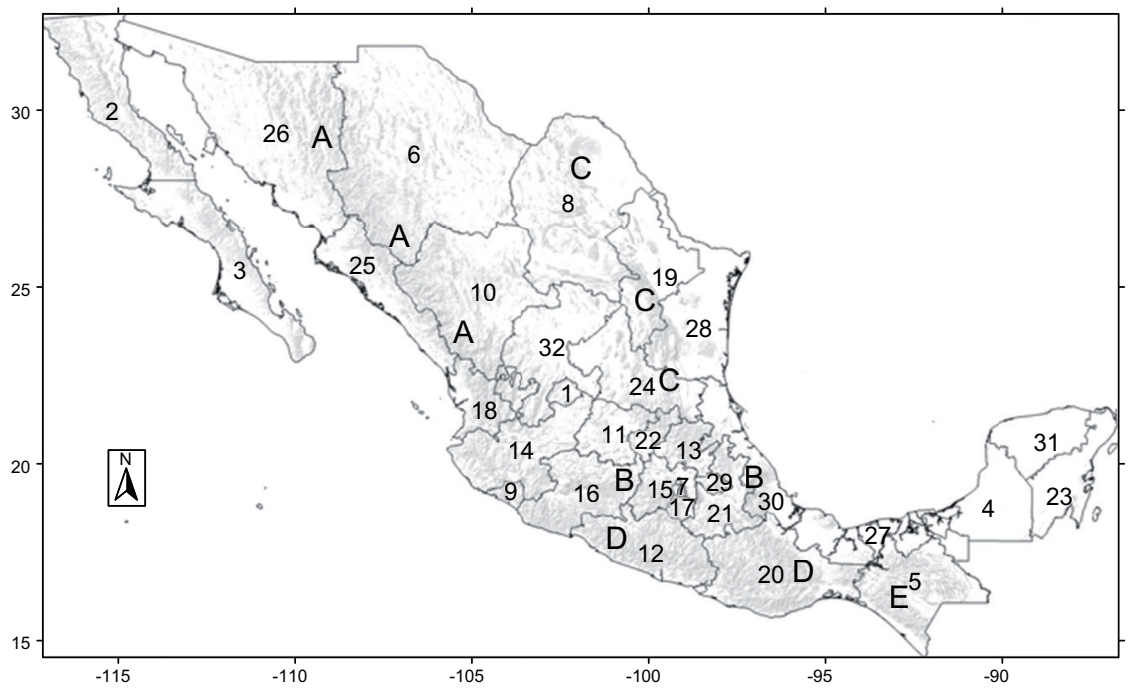

\begin{tabular}{|c|c|c|c|c|c|}
\hline & State & $\begin{array}{l}\mathrm{km}^{2} \text { per } \\
\text { station }\end{array}$ & & State & $\begin{array}{l}\mathrm{km}^{2} \text { per } \\
\text { station }\end{array}$ \\
\hline 1 & Aguascalientes & 77.81 & 17 & Morelos & 66.84 \\
\hline 2 & Baja California & 521.53 & 18 & Nayarit & 371.43 \\
\hline 3 & Baja California Sur & 450.66 & 19 & Nuevo León & 373 \\
\hline 4 & Campeche & 709.96 & 20 & Oaxaca & 269.42 \\
\hline 5 & Campeche & 250.21 & 21 & Puebla & 151.8 \\
\hline 6 & Chihuahua & 886.95 & 22 & $\begin{array}{l}\text { Querétaro de } \\
\text { Arteaga }\end{array}$ & 188.69 \\
\hline 7 & Ciudad de México & 25.34 & 23 & Quintana Roo & 757.71 \\
\hline 8 & $\begin{array}{c}\text { Coahuila de } \\
\text { Zaragoza }\end{array}$ & 1316.22 & 24 & San Luis Potosí & 325.2 \\
\hline 9 & Colima & 104.2 & 25 & Sinaloa & 349.79 \\
\hline 10 & Durango & 761.22 & 26 & Sonora & 631.53 \\
\hline 11 & Guanajuato & 191.29 & 27 & Tabasco & 297.96 \\
\hline 12 & Guerrero & 270.62 & 28 & Tamaulipas & 403.26 \\
\hline 13 & Hidalgo & 143.54 & 29 & Tlaxcala & 72.67 \\
\hline 14 & Jalisco & 291.07 & 30 & $\begin{array}{c}\text { Veracruz de } \\
\text { Ignacio de la } \\
\text { Lave }\end{array}$ & 204.05 \\
\hline 15 & México & 64.41 & 31 & Yucatán & 416.04 \\
\hline 16 & $\begin{array}{c}\text { Michoacan de } \\
\text { Ocampo }\end{array}$ & 249.36 & 32 & Zacatecas & 470.53 \\
\hline
\end{tabular}

Fig. 1. Political division, mountain ranges and station coverage (A, Sierra Madre Occidental; B, Eje Neovolcánico; C, Sierra Madre Oriental; D, Sierra Madre del Sur; E, Sierra de Chiapas).

is a narrow, mountainous fringe no more than $200 \mathrm{~km}$ wide and about $1000 \mathrm{~km}$ long, as illustrated in Figure 1.

Mexico lies between latitudes $14^{\circ}-32^{\circ}$ north and longitudes $87^{\circ}-117^{\circ}$ west. Its location and orography allow for a great variety of climates, from arid in the northern part of the country, to tropical and humid in the south. In winter, meteorological systems of higher latitudes reach the central part of the country, being more remarkable in the coastal states of the Gulf of Mexico and at the high parts of the mountain ranges, producing precipitation and a decrease in temperature. During summer, there is an increase in temperature and rains that cover more than half of the southern territory, trade winds migrate toward north bringing humidity to the country, where they 
ascend the mountains causing orographic rains (Wallen, 1955; Mosiño, 1959; García, 2003). In addition, tropical cyclones affect both coasts and produce large amounts of rain in the southern and central states; the main affected regions are the Yucatán and Baja California peninsulas.

\subsection{Data set and seasonal characterization}

We used the CLICOM (CLImate COMputing project) data base, a climate data managing software developed by the United Nations. Daily observations represent the last $24 \mathrm{~h}$ ending at 08:00 LT. In Mexico, this database is managed by the Servicio Meteorológico Nacional (National Meteorological Service), which integrates 5404 climate stations reporting precipitation since the early twentieth century (http://clicom-mex.cicese.mx); however, only a few stations have continuous records up to the present. The stations coverage $\left(\mathrm{km}^{2}\right)$ along the territory is shown in Figure 1.

As shown in Figure 2, the number of active stations decreased dramatically since 1991. Their distribution, selected according to criteria later explained, is rather inhomogeneous, being denser south of parallel $22^{\circ} \mathrm{N}$ (see Figs. 3 and 5); to the north and in areas of low population the station density is lower. For example, in Coahuila each station covers an area of $1318 \mathrm{~km}^{2}$, while in Mexico City it covers $25 \mathrm{~km}^{2}$. The inhomogeneity, which is related to population, is inherent to the data basis, and the absence of observations due to diverse causes is an additional shortcoming.

In order to keep the largest number of stations in spite of previously discussed limitations, the period 1961-2013 was divided into two periods: 1961-1990 and 1991-2013, the first period is long enough to estimate climate normals and may serve as comparison criterion. This procedure allows to achieve the greatest coverage and continuity of stations, and to compare the consistency of results for both periods. The dry/cold and rainy/warm seasons were studied separately; in northwestern Mexico, the wet season coincides with the cold season, whereas in the rest of the country, the warm season is rainy.

The amount of information required for a station to be used in the analysis was set as follows: each month had to be at least 27 days; each season should have six months, and at least 20 seasons should be considered. In the first period (1961-1990) the selection procedure yielded 1530 stations for the warm season and 1875 for the cold season; in the second period (1991-2013), 1008 and 997 stations were yielded for warm and cold seasons, respectively. To satisfy that each and every month has the same weighting for the average calculus, despite the number of observed days (27 to 31 ), monthly

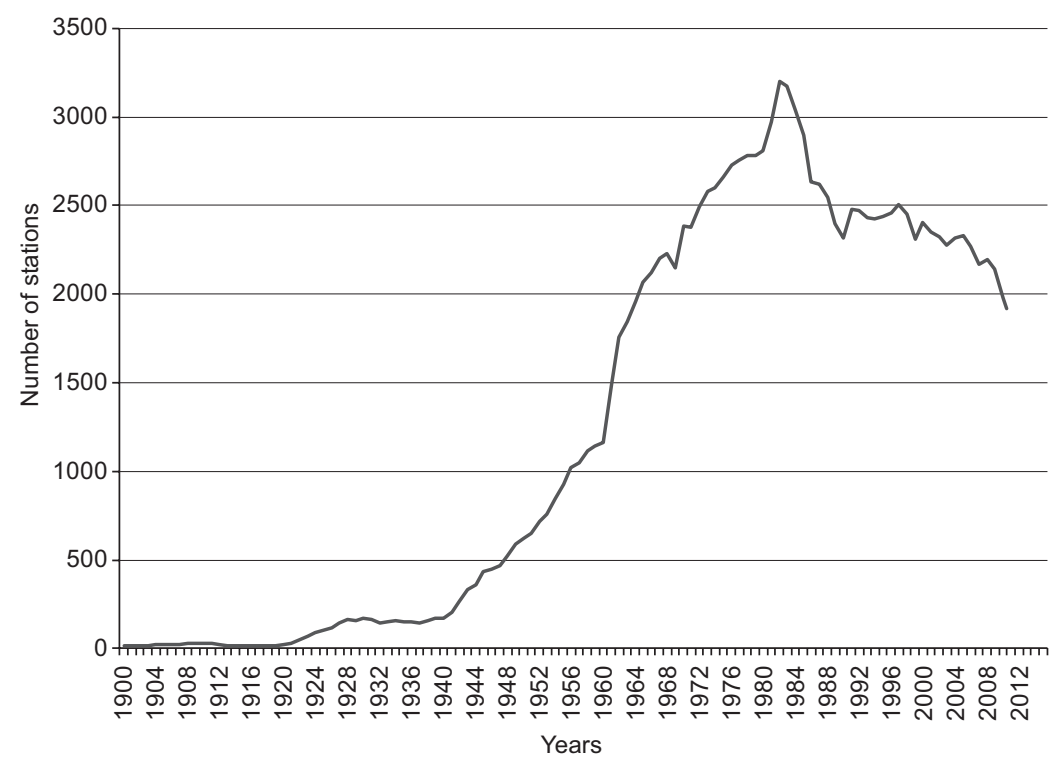

Fig. 2. Number of active stations since 1900. 


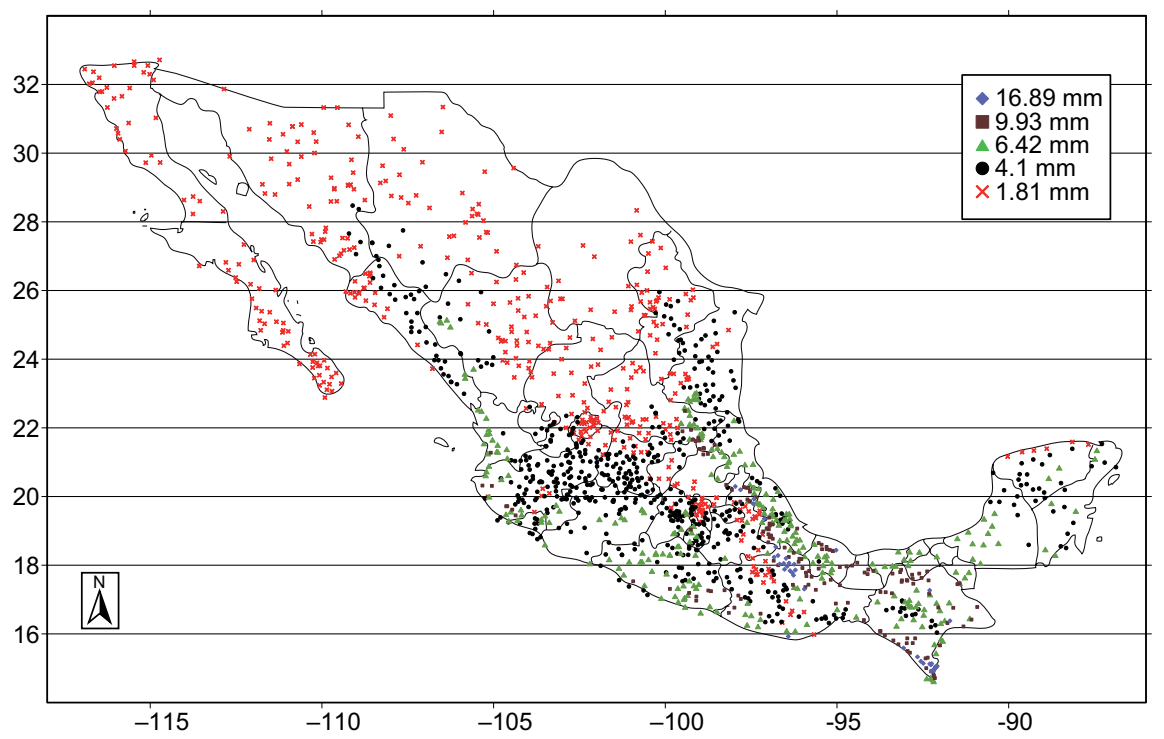

Fig. 3. Distribution of climate stations and normal precipitation in the warm season.

and season averages of daily precipitation were calculated.

The Multivariate ENSO Index (MEI) has been extensively used to indicate the presence and intensity of El Niño. This index considers six atmospheric and oceanic variables, which are sea-level pressure $(\mathrm{P})$, zonal $(\mathrm{U})$ and meridional $(\mathrm{V})$ components of the surface wind, sea surface temperature (S), surface air temperature (A), and total cloudiness fraction of the sky $(\mathrm{C})$. This set of data reflects the nature of the coupled ocean-atmosphere system better than either component alone (Wolter and Timlin, 1993). Positive (negative) values above (below) $0.5(-0.5)$ are associated to the positive (negative) phase of ENSO. This index is used to find out the relationship between rainfalls in Mexico and how it is affected by ENSO, by means of the Pearson product-moment correlation coefficient (Pearson's correlation, for short).

\subsection{Statistical methods}

The Pearson's correlation coefficient for a sample,

$r=\frac{\sum_{i=1}^{n}\left(x_{i}-\bar{x}\right)\left(y_{i}-\bar{y}\right)}{\sqrt[2]{\left(x_{i}-\bar{x}\right)^{2}} \sqrt[2]{\left(y_{i}-\bar{y}\right)^{2}}}$,

is a measure of the strength and direction of linear association that exists between two variables, and its values are $-1 \leq r \leq 1$; positive (negative) values indicate a direct (inverse) relation between them; $r=1$ or $r=-1$ means an exact linear relation. It was calculated for the average MEI and average precipitation. The use of this coefficient requires the data to fulfill the following four conditions (Laerd Statistics, 2003):

1. Both variables should be measured at the interval or ratio level, i.e., they must be continuous.

2. A linear relationship between the two variables exists.

3. There should be no significant outliers.

4. The variables should be approximately normally distributed.

In order to assess the statistical significance of the Pearson correlation, the variables require having a bivariate normal distribution. As this is difficult to evaluate, a simpler method is more commonly used: checking the normality of the variables.

Since daily precipitation values may be large, then their frequency distributions are right skewed, so it is necessary to obtain annual or seasonal averages to get an approximate symmetrical Gaussian-type distribution, given that the average procedure smooths out the bigger values (Sánchez-San Román, 2008). On the other hand, using the chi-square and Kolmogorov-Smirnov tests, the MEI distribution does not differ significantly $(p<0.05)$ from a Gaussian distribution. 

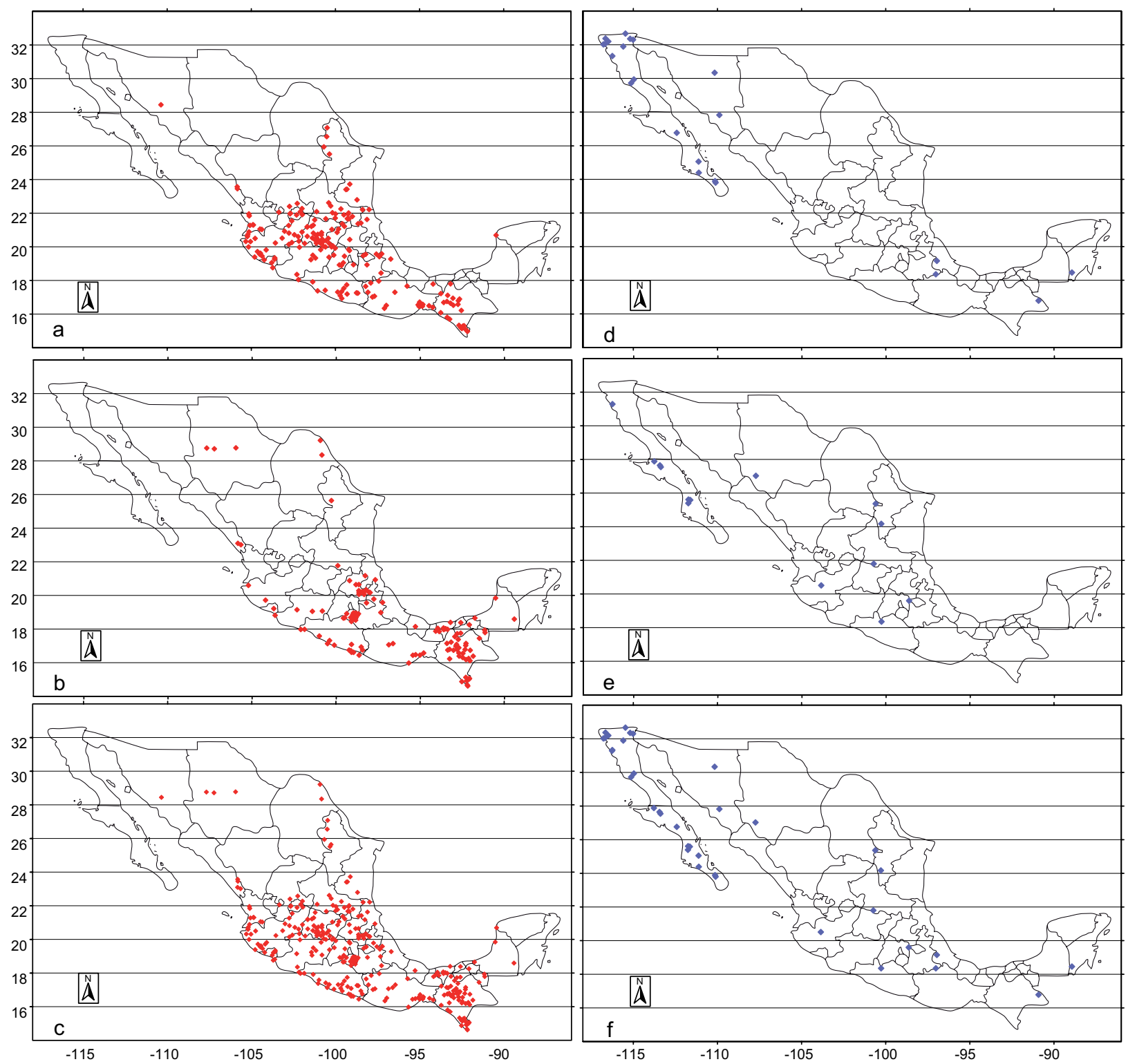

Fig. 4. Left column, from top to bottom (a through c), negative correlation maps for the periods 1961-1990, 1991-2013, and 1961-2013. Similarly for right column (d through f), but for positive correlation for warm season.

Thus, the significance for the samples in the Pearson's correlation coefficient can be calculated by commonly used methods. The null hypothesis is $H_{0}: r=0$; i.e., there is no linear correlation between the precipitation and MEI values, against $H_{1}: r \neq 0$, i.e., there is some linear correlation between variables. When the null hypothesis is true, the distribution of the parameter $t$ is calculated by means of the correlation coefficient $r$ with a sample of size $N$, and should have a Student distribution with $N-2$ degrees of freedom: $t=\frac{r}{\operatorname{sqrt}\left[\left(1-r^{2}\right) /(N-2)\right]}$,

If the values of $t$ exceed the limits of a 2-tailed $95 \%$ test, then the no correlation hypothesis between variables is rejected; i.e., a positive or negative correlation exists between them (Hogg and Craig, 1970).

Since the relationship between rainfall and ENSO is studied, it is necessary to establish reference or 


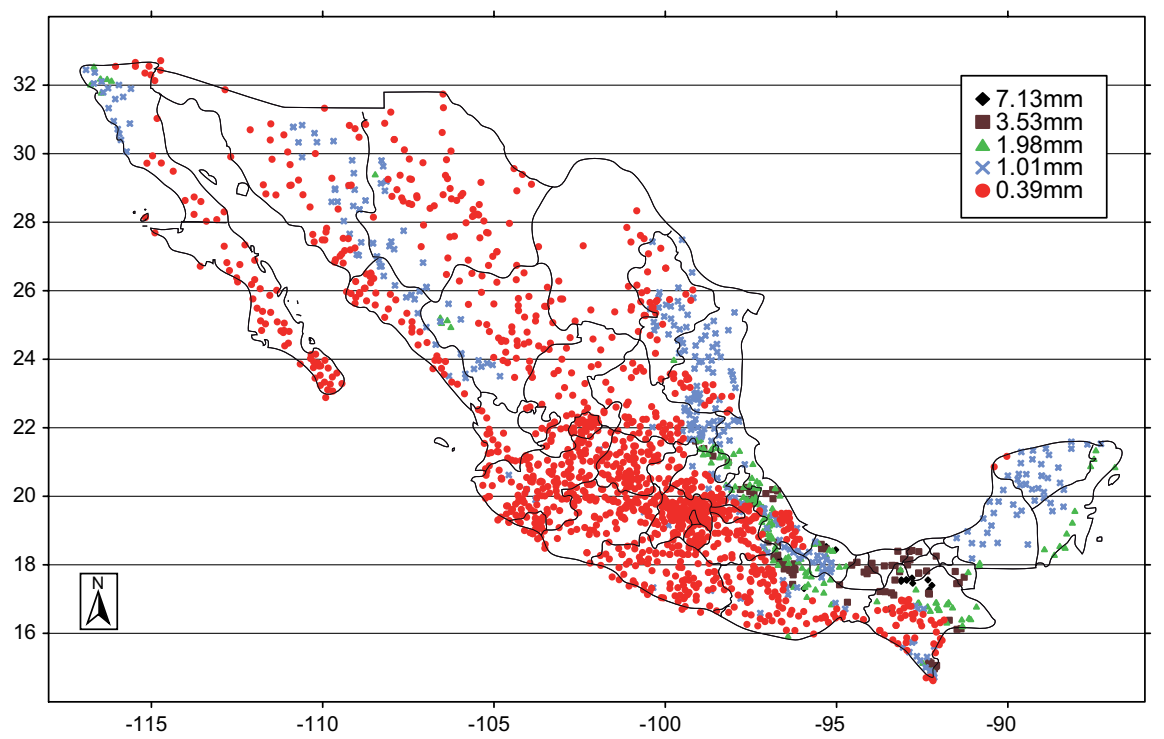

Fig. 5. Stations distribution and precipitation during the cold season.

normal values of precipitation. Distribution of rain along Mexico was obtained by K-means clustering. This method was used for classifying the stations into five groups of precipitation (Everitt et al., 2011). The aim of $\mathrm{K}$-means clustering is to divide $M$ points of $N$ dimensions into $K$ clusters so that the within-cluster sum of distances is minimized (Hartigan and Wong, 1979). This method allows defining geographic areas with similar characteristics in an objective approach. As stated previously, the stations were classified for both the warm/rainy and cold/dry seasons. The total amount for warm season precipitation is obtained by multiplying each cluster value by 184 (May-October); similarly, the cold season (November-April) amount is found by multiplying by 181 (or 182 if the previous year was a leap one).

\section{Results}

\subsection{Warm/rainy season}

In the warm season (May to October), the weather in Mexico is influenced by low-latitude systems, which cause a rise in precipitation. Such systems include the trade winds, tropical waves and, occasionally, the entrance of tropical cyclones. These systems are manifested mainly in the establishment of the rain season, although this is not noticeable in the northwestern part of the country where it spans from November to April. Figure 3 shows the geographical distribution of weather stations and their classification according to the K-means method.

The summer rainfall geographical distribution is defined by five clusters: from 1.81 to $16.89 \mathrm{~mm}$ day-season $^{-1}$. The group of lower value $(1.81 \mathrm{~mm} /$ day-season, red crosses) occupies the northwestern and north states, limited by both the Sierra Madre Oriental and Occidental. It also covers a central strip oriented SE-NW. From the Gulf of Mexico, the precipitation increases until a maximum, related to the eastern slope of the Sierra Madre Oriental. The Yucatán Peninsula is not a region of high rainfall during summer, perhaps due to the absence of orographic elevations.

On the Pacific shoreline, rain increases in magnitude from north to south from $1.81 \mathrm{~mm}^{\text {day-season }}{ }^{-1}$ in Sonora to $16.89 \mathrm{~mm}^{\text {day-season }}{ }^{-1}$ in Chiapas, with intermediate amounts in the other states. On the slopes of the Sierra de Chiapas, the presence of the ITCZ and the passage of tropical waves produce rain in the southern states; however, this effect diminishes as latitude increases.

The relationship between precipitation and ENSO is determined by calculating the Pearson correlation coefficient as mentioned previously. Figure 4 shows the stations with significant values $(p<0.05)$ for the warm season during the1961-1990 period. Despite dispersion, stations with positive correlation clearly identify the northwestern region, in agreement 

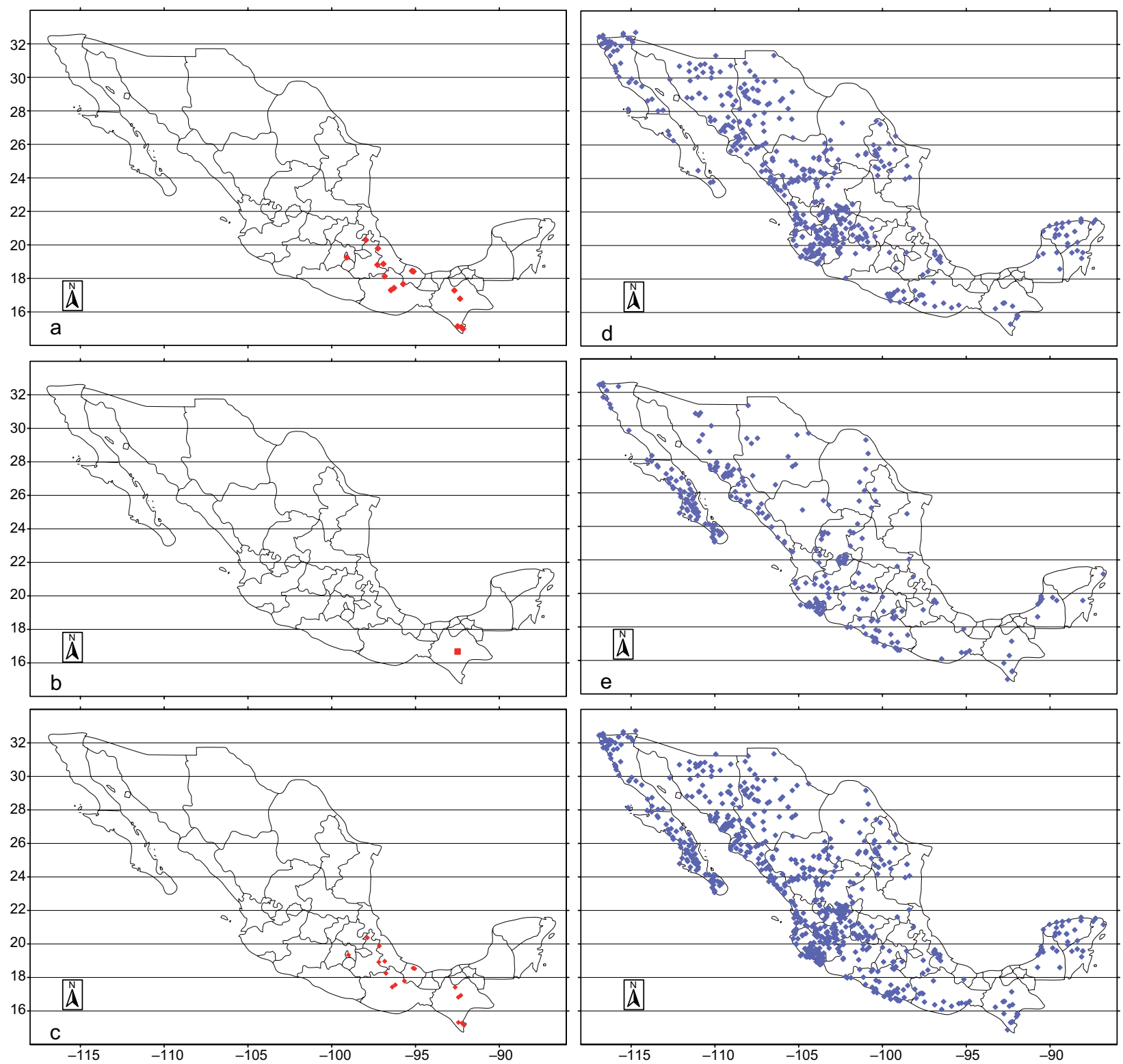

Fig. 6. Left column, from top to bottom (a through c), negative correlation maps for 1961-1990, 1991-2013 and 19612013 periods. Similarly for right column (d through f), but for positive correlation for cold season.

with Cavazos and Hastenrath (1990), Salinas et al. (1990), Englehart and Douglas (2002) and Magaña et al. (2003); however, the rest of the stations are distributed without a clear pattern, this result is in disagreement with Salas-Flores et al. (2014) who found influence on the Yucatán Peninsula. The southern half of the country (except for the Yucatán Peninsula) is dominated by a decline in the rain with the presence of El Niño, also the northern part of the Sierra Madre Oriental shows a decrease in rainfall.
Figure 4 shows the result of the correlation coefficient between ENSO and rainfall in Mexico. The left column displays, from top to bottom, the periods 1961-1990, 1991-2013, and the union of both. The distribution of negative correlation is approximately the same for the first row; however, the density of stations is lower for the second period (second row) because there are fewer stations for the period 19912013. Under this premise, a third map was elaborated with the union of both periods, in which it is clear 
that the areas where ENSO negatively affects precipitation are preserved.

Similarly, the right column of Figure 4 shows a positive correlation coefficient between ENSO and precipitation; notwithstanding the number of stations is lower the areas of positive correlation are also preserved in the two periods. The union of stations is in the lower row.

The complete span of time is obtained by adding both periods, which permits to have a higher density of stations and identify regions more clearly. Figure $4 \mathrm{f}$ shows that only in the northwestern area of the country, during the positive phase of ENSO, precipitation increases, in agreement with Englehart and Douglas (2006) and Walkowiak and Solana (1989); although, there are some other isolated stations with the same feature. On the other hand, rain decreases to the south of parallel $22^{\circ} \mathrm{N}$ except for the Yucatán Peninsula, where there are only few significant stations (see Fig. 4c).

\subsection{Cold/dry season}

Winter precipitation was also classified into five clusters (Fig. 5), which range from 0.19 to $7.13 \mathrm{~mm}$ day-season $^{-1}$. The cluster with the smallest amount of precipitation happens to be the most widespread and as such it virtually covers the entire coastal plain of the Pacific, from Chiapas to Sonora and most of the Baja California peninsula. The northern part of Baja California, as well as the southern tip of Chiapas, has more rainfall, up to 1.98 and 3.53 mm day-season ${ }^{-1}$, respectively; this conglomerate, interrupted by a strip parallel to the coast with an amount of $1.01 \mathrm{~mm}$ day-season ${ }^{-1}$, occupies almost the western half of the country. In the Gulf of Mexico slope, the interaction between the winds and the Sierra Madre Oriental is evident: the groups have precipitations ranging from 1.01 to $1.98 \mathrm{~mm}$ day-season $^{-1}$ on the windward side of the mountains. More substantial amounts are found in the Tabasco and Chiapas Northern mountains.

During winter, cold fronts extend farther south, and the abaft anticyclone causes what is known as a "north": cold and heavy air moving from East that does not surpass the Sierra Madre Oriental and, therefore, produces northerly winds on the coastal plain. In addition, interaction with the mountains produces clouds and precipitation that occasionally reaches the central part of the Eje Neovolcánico (Trans-Mexican Volcanic Belt). The remoteness of the ITCZ and the absence of tropical waves are manifested by low rainfall along the Pacific coast, center, and north of the country. The influence of orography in winter precipitation is clearly seen on the mountain slopes toward the Gulf of Mexico, the northern mountains of Chiapas and the Tabasco coast, where a larger amount is noted. In the Yucatán peninsula, cold fronts can produce some rain. In the northwestern part of the country, there is a small region of highest rainfall associated with the presence of westerlies.

The correlation of El Niño with precipitation during the winter (1961-1990) shows that most of the territory responds directly (Fig. 6d); that is, if the MEI increases (decreases), precipitation increases (decreases). On the slopes toward the Gulf of Mexico also in Oaxaca, Chiapas, Guerrero and Michoacán, there is a clear absence of stations with positive correlation. Stations with negative correlation are dispersed along the southern part of the Sierra Madre Oriental and the Sierra Madre del Sur (Fig.6a). Similarly, in the 1991-2013 period, the coverage of stations with significant positive correlation extends over most of the country; Baja California Sur and Guerrero show an even greater presence of stations (Fig. 6e). There is only one station in Chiapas where precipitation decreases with the increasing value of MEI (Fig. 6b).

The entire interval (1961-2013) was analyzed (Fig. 6c, f); it is notable that no changes are seen in the areas covered by positive or negative correlations, the difference is only evidenced by the number of stations. During the cold season, most of the territory has an increased amount of rain when El Niño occurs. In the Veracruz region of the Tehuantepec Isthmus, there is a lack of stations with significance. This deficiency might be the cause of the apparent decrease in precipitation found by Magaña et al. (2003), who suggested it was due to the quick passage of the "norths".

\section{Discussion and concluding remarks}

El Niño involves coupled ocean waves and changes in atmospheric circulation (Bjerknes, 1969). It is probably preceded by the weakening of trade winds on the Central Pacific, and it is also related to strengthening of westerly wind burst's (WWBs) (Luther 
et al., 1983). More frequent WWBs occurrence is also clear, according to Eisenman and Tziperman (2005); they are modulated by the presence of El Niño and they are observed to migrate eastward as El Niño does (Keen, 1982; Harrison and Vecchi, 1997). This, during winter in Mexico, is accompanied by the southward migration of the jet stream and a higher number of "norths" in the Gulf of Mexico (Magaña et al., 2003).

The atmospheric circulation in the cold season, during El Niño events, is altered in Mexico so that the westerly winds reach greater extension to the south, moving moisture and increasing precipitation from the Jalisco coast northwards, and also in the Sierra Madre Occidental. Eventually, depending on the southern extension of the trough associated with the westerly winds, if cold air is present in the near surface levels, it causes the ascent of air that produces snow to fall in the upper parts of the Eje Neovolcánico, making clear an enhancement of moisture arrival. These events are related to the well-known WWBs, which at this time of the year reach these latitudes. In the Yucatán Peninsula there is also an increase in precipitation, probably because cold fronts are more numerous in the presence of E1 Niño.

In the presence of El Niño and during the warm season, the downstream segment of the Walker cell moves eastward, causing subduction and air heating that inhibits cloud formation and precipitation on a portion of the Atlantic, the Gulf of Mexico and the Mexican territory. This fact is directly associated with the weakening of trade winds and the decreased humid air inlet to the mainland. It also decreases the amount of precipitation in Mexico's southern half. Similarly, this movement inhibits hurricane development over the North Atlantic (Jáuregui, 1967). Also, the northwestern part of the country reported an increase in precipitation during El Niño due to the variation in the position of the subtropical jet modifying the entry of maritime air and carrying moisture to the region. In addition, there is the presence of a zone with abnormally high SST.

During the warm season, south of parallel $22^{\circ} \mathrm{N}$ (excluding the Yucatán Peninsula), the presence of El Niño clearly decreases precipitation in agreement with Magaña et al. (2003). There is an increase in rain over the Baja California Peninsula and in some more continental but dispersed stations over central and western Mexico. These conditions of decreased rain might be caused by the weakening of the trade winds and the displacement of the Walker cell to the west.

In another work, Salas-Flores et al. (2014) found that the Yucatán Peninsula presents a modulation of precipitation with the ENSO positive phase; that is, the greater ENSO intensity, the clearer the increase in rainfall, a relation which is not clear in this paper because there are no stations with significant correlation in this area. Pavía et al. (2006), studying PDO-ENSO phenomena, found that in the winter season precipitation increases in the peninsulas of Baja California and Yucatán; in addition, they obtained a negative correlation with some stations of the southern states, namely Chiapas and Tabasco, corresponding with the results of this work.

Previous studies used a limited number of stations and periods that span the entire record of stations. The results of this work are in concordance with these, although ours allow a greater clarity, since a larger dataset has been used and the methodology permits to increase the number of useful stations. In this manner, it is possible to find that the behavior of the ENSO-precipitation relation in Mexico in two consecutive periods of time remains approximately unchanged.

Table I summarizes the behavior of precipitation for both seasons and in conditions of El Niño or La Niña.

Table I. Behavior of precipitation for both seasons and under conditions of El Niño or La Niña.

Cold season

\begin{tabular}{ll}
\hline \multicolumn{1}{c}{ La Niña } & \multicolumn{1}{c}{ El Niño } \\
\hline $\begin{array}{l}\text { Precipitation decreases in } \\
\text { almost the whole country } \\
\text { but increases in some } \\
\text { southern stations }\end{array}$ & $\begin{array}{l}\text { Precipitation increases } \\
\text { across almost all the country } \\
\text { and decreases in some } \\
\text { southern stations }\end{array}$ \\
\hline \multicolumn{2}{c}{ Warm season } \\
\hline \multicolumn{1}{c}{ La Niña } & \multicolumn{1}{c}{ El Niño } \\
$\begin{array}{l}\text { Precipitation increases in } \\
\text { the south and decreases } \\
\text { northwest of the country }\end{array}$ & $\begin{array}{l}\text { Precipitation decreases } \\
\text { in south and increases } \\
\text { northwest of the country }\end{array}$ \\
\hline
\end{tabular}




\section{Acknowledgments}

We thank M. E. Alcántara, J. M. Espíndola and C. O. Márquez for revising the English version of the manuscript; also C. Salas Ángeles for her help in the preparation of the figures.

\section{References}

Bjerknes J., 1969. Atmospheric teleconnections from the equatorial Pacific. J. Phys. Oceanogr. 97, 163-172. doi: 10.1175/1520-0493(1969)097<0163:atftep $>2.3$. co;2

Bond N.A. and D.E. Harrison, 2000. The. Pacific Decadal Oscillation, air-sea interaction and central north Pacific winter atmospheric regimes. Geophys. Res. Lett. 27, 731-734. doi: 10.1029/1999GL010847

Bravo J.L., E. Azpra, V. Zarraluqui, C. Gay and F. Estrada, 2010. Significance tests for the relationship between "El Niño" phenomenon and precipitation in Mexico. Geofis. Int. 49, 245-261.

Cavazos T. and S. Hastenrath, 1990. Convection and rainfall over Mexico and their modulation by the Southern Oscillation. Int. J. Climatol. 10, 377- 386. doi: $10.1002 /$ joc. 3370100405

Eisenman I., L. Yu and E. Tziperman, 2005. Westerly wind bursts: ENSO's tail rather than the dog? J. Climate 18, 5224-5238. doi: 10.1175/JCLI3588.1

Elsner J.B. and B. Kocher, 2000. Global tropical cyclone activity: a link to the North Atlantic Oscillation. Geophys. Res. Lett. 27, 129-13. doi: 10.1029/1999GL010893

Englehart P.J. and A. V. Douglas, 2002. Mexico's summer rainfall patterns: an analysis of regional modes and changes in their teleconnectivity. Atmósfera 15,147-164.

Englehart P.J. and A.V. Douglas, 2006. Defining intraseasonal rainfall variability within the North American Monsoon. J. Climate 19, 4243-4253.

Everitt B.S., S. Landaw, M. Leese and D. Stahl, 2011. Cluster analysis. Wiley Series in Probability and Statistics, 346 pp. DOI: 10.1002/9780470977811

García E., 2003. Distribución de la precipitación en la República Mexicana. Invest. Geog. 50, 67-76.

Glantz M.H., 2000. Currents of change impacts of El Niño and La Niña on climate and society, 2nd ed. Cambridge University Press, Cambridge, 268 pp.

Gray W. M., 1984. Atlantic seasonal hurricane frequency: El Niño and $30 \mathrm{mb}$ quasi biennal oscillation influences. Mon. Wea. Rev. 112, 1649-1668.

doi: 10.1175/1520-0493(1984)112<1649:ASHF$\mathrm{PI}>2.0 . \mathrm{CO} ; 2$
Harrison D.E. and G.A. Vecchi, 1997. Westerly wind events in the tropical Pacific, 1986-95. J. Climate 10, 3131-3156.

doi: 10.1175/1520-0442(1997)010<3131:WWEIT$\mathrm{T}>2.0 . \mathrm{CO} ; 2$

Hartigan J.A. and M.A. Wong, 1979. Algorithm AS 136: A K-Means clustering algorithm. doi: 10.2307/2346830

Haug G.H., D. Günther, L.C. Peterson, D.M. Sigman, K.A. Hughen and B. Aeschlimann, 2003. Climate and the collapse of Maya civilization. Science 299 1731-1735. doi: 10.1126/science. 1080444

Hogg R.V. and A.T. Craig, 1970. Introduction to mathematical statistics. Collier Macmillan Publishers, London, $225 \mathrm{pp}$.

Jáuregui O.E., 1967. Las ondas del Este y los ciclones tropicales en México. Ing. Hidr. Méx. 21, 197-208.

Keen R.A., 1982. The role of cross-equatorial tropical cyclone pairs in the Southern Oscillation. Mon. Weather Rev. 110, 1405-1416.

doi: 10.1175/1520-0493(1982)110<1405:TRO$\mathrm{CET}>2.0 . \mathrm{CO} ; 2$

Laerd Statistics, 2003. Pearson's product-moment correlation using SPSS statistics. Available at: https:// statistics.laerd.com/spss-tutorials/pearsons-product-moment-correlation-using-spss-statistics.php.

Luther D., D. Harrison and R. Knox, 1983. Zonal wind in the central equatorial Pacific and El Niño. Science, 202, 327-330. doi: 10.1126/science.222.4621.327

Magaña V.O., J.L. Vázquez, J.L. Pérez and J.B. Pérez, 2003. Impact of El Niño on precipitation in Mexico. Geofís. Int. 42, 313-330.

Mantua J., S.R. Hare, Y. Zhang, J.M. Wallace and R.C. Francis, 1997. A Pacific interdecadal climate oscillation with impacts on salmon production. Bull. Am. Meteorol. Soc. 78, 1069-1079. doi: 10.1175/1520-0477(1997)078<1069:API$\mathrm{COW}>2.0 . \mathrm{CO} ; 2$

Méndez J., A. Ramírez, E. Cornejo, A. Zárate and T. Cavazos, 2010. Teleconnection of the Pacific Decadal Oscillation (PDO) to the precipitation and temperature in Mexico. Invest. Geog. 73, 57-70 pp.

Mosiño A.P., 1959, La precipitación y las configuraciones del flujo aéreo en la República Mexicana. Ing. Hidr. Méx. 13, 1-12.

Pavía López E.G., F. Graef Ziehl and J. Reyes Rodríguez de la Gala, 2006. PDO-ENSO effects in the climate of Mexico. J. Climate, 19, 6433-6438. doi: $10.1175 / J C L I 4045.1$ 
Salas-Flores M.A., M.E. Hernández-Cerda, J. Villicaña-Cruz, E. Azpra-Romero and C.T. Lomas-Barrié, 2014. The influence of strong El Nino phases on the rainfall over the Yucatan Peninsula, Mexico. Scientific Annals of the Alexandru Ioan Cuza University of Iaşi, LX (Geography Series).

doi: 10.15551/scigeo.v60i1.315

Salgado S.K., L. Dávila y A.M. Pérez, 2014. México y sus estados. Ediciones Culturales Internacionales, $256 \mathrm{pp}$.

Salinas Zavala C.A., A. Leyva Contreras, D. Lluch Belda and E. Díaz Rivera, 1990. Distribución geográfica y variabilidad climática de los regímenes pluviométricos en Baja California Sur, Mexico. Atmósfera 3, 217-237.

Sánchez San Román F.J., 2008. Distribuciones estadísticas. Available at: http://hidrologia.usal.es/Complementos/ estadistica/distr_esta.pdf.Wilks D., 2011. Statistical methods in the atmospheric sciences, 3rd. ed. Int. Geophys. 100, 2-676.

Schlesinger M.E. and N. Ramankutty, 1994. An oscillation in the global climate system of period 65-70 years. Nature 367, 723-726. doi:10.1038/367723a0

Stahle D.W., E.R. Cook, D.J. Burnette, J. Villanueva, J. Cerano, J.N. Burns, D. Griffin, B. I. Cook, R. Acuña,
M.C.A. Torbenson, P. Sjezner and I.M. Howard, 2016. The Mexican drought atlas: Tree-ring reconstructions of the soil moisture balance during the late pre-Hispanic, colonial, and modern eras. Quat. Sci. Rev. 149, 34-60.

doi: 10.1016/j.quascirev.2016.06.018

Walkowiak A.M. and E. Solana, 1989. Distribución estacional de lluvias en Baja California, México. Análisis de Probabilidades. Atmósfera 2, 209-218.

Wallen C.C., 1955. Some Characteristics of precipitation in México. Geogr. Ann. Svenska Sällsk. Antropol. 37, 51-85.

Wang Ch. and S.K. Lee, 2009. Co-variability of tropical cyclones in the North Atlantic and the eastern North Pacific. Geophys. Res. Lett. 36, L24702. doi:10.1029/2009GL041469.

Wolter K., and M.S. Timlin, 1993. Monitoring ENSO in COADS with a seasonally adjusted principal component index. Procedures of the 17th Climate Diagnostics Workshop, Norman, Oklahoma. NOAA/NMC/CAC, NSSL, Oklahoma Climate Survey, CIMMS and the School of Meteorology, University of Oklahoma, 52-57. 